\title{
Hinterland History: The Ok Tedi Mine \\ and Its Cultural Consequences in \\ Telefolmin
}

Dan Jorgensen

Introduction: Mining and Local People in Papua New Guinea

Papua New Guinea's position on a global resource frontier has been one of the country's defining features since independence in I975. Mining, logging, and the petroleum industry account for most of the country's income, with mining providing the lion's share. State finances depend on revenues generated by resource projects, and policy governing such matters has become a key focus of national political debate. The fact that national planning relies on resource projects has lent a particular urgency to the state's relation to rural people in resource-rich regions, and the status of "landowner" signals a position of power from which citizens can confront a state and developers anxious to bring projects into production (Filer I997a, I62-165).

The history of the state's relation to landowners in the vicinity of mining projects has been fraught with contention. The nation's single most traumatic political crisis burst on the scene at the close of the I980s, when landowners on Bougainville transformed a dispute about their relation to the Panguna mine into a full-scale secessionist rebellion. The fighting lasted longer than the Second World War, and the details of peace arrangements and restoration of services are still being worked out to this day.

When landowners began dynamiting mine facilities on Bougainville, national revenues suffered a severe shock (see Filer I990, I998; May and Spriggs 1990). Yet despite this catastrophic loss, the PNG economy rebounded quickly as other projects came on stream, and by the early I990s the country was in the middle of a resource boom. The gross

The Contemporary Pacific, Volume I8, Number 2, 233-263

(C) 2006 by University of Hawai'i Press 
domestic product grew at extraordinary rates, a surge that only abated in the late I990s. By that time mining exploration activities subsided, in part as a corporate response to difficulties encountered in relations with landowners at various projects, including the Panguna and Porgera mines, the Kutubu and Moran oil projects, the Hides gas project, and the Ok Tedi mine discussed in this article (see Banks 2002a). The PNG economy is now in precarious shape, a fact that has done nothing to reduce the state's concern with landowner relations where minerals are involved.

Although all mining projects are legally required to produce social and environmental impact studies, until recently relatively little research was published on such matters. Most of what is known about the social context of mining projects exists in news reports and the grey literature of internal government documents, consultants' reports, and the files of various nongovernmental organizations. Despite this, scholarly literature on local people and resource development in Papua New Guinea is now emerging, especially under the joint auspices of various PNG institutions and the Australian National University's Resource Management in AsiaPacific program (eg, Kirsch I993; Banks and Ballard 1997; Toft I997; Filer I999; Macintyre and Foale 2004; see also Brown and Ploeg 1997; Connell and Howitt I99I; Howitt and others 1996). For reasons that are understandably related to policy matters, much of this new literature is specifically concerned with indigenous people as landowners and examines the principles, mechanics, and consequences of compensation arrangements. These studies-particularly those concerning the Ok Tedi environmental lawsuit (more about this below; see also Banks and Ballard 1997) and the collection of papers on the social impact of the Porgera mine (Filer 1999) - have begun to give us a clearer idea of the ways in which local communities have been affected by mining (see also Rumsey and Weiner 200I).

In this article, however, I am concerned to step back a bit from the immediate issues of landowner compensation and instead address a major mining project from the perspective of its long-term consequences on those who occupy its hinterland. Such people on the peripheries of mining projects are not recognized as landowners with respect to resource rents, and are sometimes referred to as "unofficial stakeholders" (Filer I997b, 254; see also Jacka 200Ia). Mining operations have large-scale ripple effects throughout surrounding regions, particularly where government efforts have been negligible and alternative prospects scarce. Such hinterland regions comprise zones in which local people may have a wide range of relations to mining projects, and part of my aim here is to document the 
dynamics of such relations with an eye to understanding the social and cultural changes that ensue from them.

My focus is on the Telefolmin people of Papua New Guinea's West Sepik Province, who have nearly a generation's experience with the Ok Tedi mine. While I would hesitate to suggest that the Telefol experience is typical-indeed, part of what I wish to show is that even within a single ethnic group there is important variability-I think the Telefol case is particularly instructive with regard to local engagements with mining projects over time. The contemporary shape of Telefol society has been powerfully affected by the Ok Tedi mine. On the one hand, Ok Tedi provides Telefolmin with the ability to realize a particular form of development that includes access to cash, services, and sought-after experiences of modernity. On the other hand, it also sharpens fears and risks of marginalization and the possibility of being left out of modernity's promise. These are themes to which I return at the end of this article. First, however, I provide some necessary background on the regional dimensions of the $\mathrm{Ok}$ Tedi project.

\section{The Impact of the Ok Tedi Project:}

\section{A Regional Overview}

The Ok Tedi mine is located in the Star Mountains in the northwestern corner of Western Province (see maps I and 2). The project was the country's first major post-independence mining operation, embarked on as part of a national strategy of garnering revenue for the state and its development plans. Begun in the early I980s, it comprises an open-pit copper mine and milling facilities that reduce the ore to concentrate. The concentrate is then sent via pipeline to the river port of Kiunga, where it is loaded onto barges for shipment.

Previously a minor mission and administration outpost (population of approximately 50 in the mid-I960s; see O'Connor I994), Kiunga has become the major logistical center for Ok Tedi, and is the point of access for supplies shipped 800 kilometers upriver from the coast. These are trucked along a specially built highway connecting Kiunga to Ok Tedi's headquarters at Tabubil. Tabubil is a new township located downslope from the mine site at the transition to the foothills giving way to the lowland plains. Equipped with a high school, hotel, banks, supermarkets, and an airstrip boasting connections to Port Moresby and Australia, Tabubil serves as the administrative, commercial, and residential center for the $\mathrm{Ok}$ 
Tedi workforce. The growth of Kiunga (population 8,300 in 2000) and the establishment of Tabubil (population I0,000) are two of the more obvious consequences of the Ok Tedi project. Beyond their mere presence as the Western Province's only urban areas apart from the provincial capital (Daru), these towns and their associated infrastructure serve as the main links between a scattered rural population and the outside world. ${ }^{1}$

The rural population most strongly affected by Ok Tedi numbers approximately 45,000 and comprises the inhabitants of the Kiunga and Tabubil Districts of Western Province, along with people of the adjacent Telefomin District in the West Sepik Province. The region's population can be subdivided into two major groups: the mountain people to the north, and the people of the southern foothills and plains. ${ }^{2}$

The mountain people all acknowledge a generic identity as "Min" people who share features of culture, language, and, most importantly, a mythology of descent from a common ancestress (known as Afek) credited with founding a regional initiation and fertility cult (Jorgensen 1996). Min subsistence is based on shifting cultivation of taro or sweet potato combined with pig husbandry and hunting. Settlement patterns vary from one

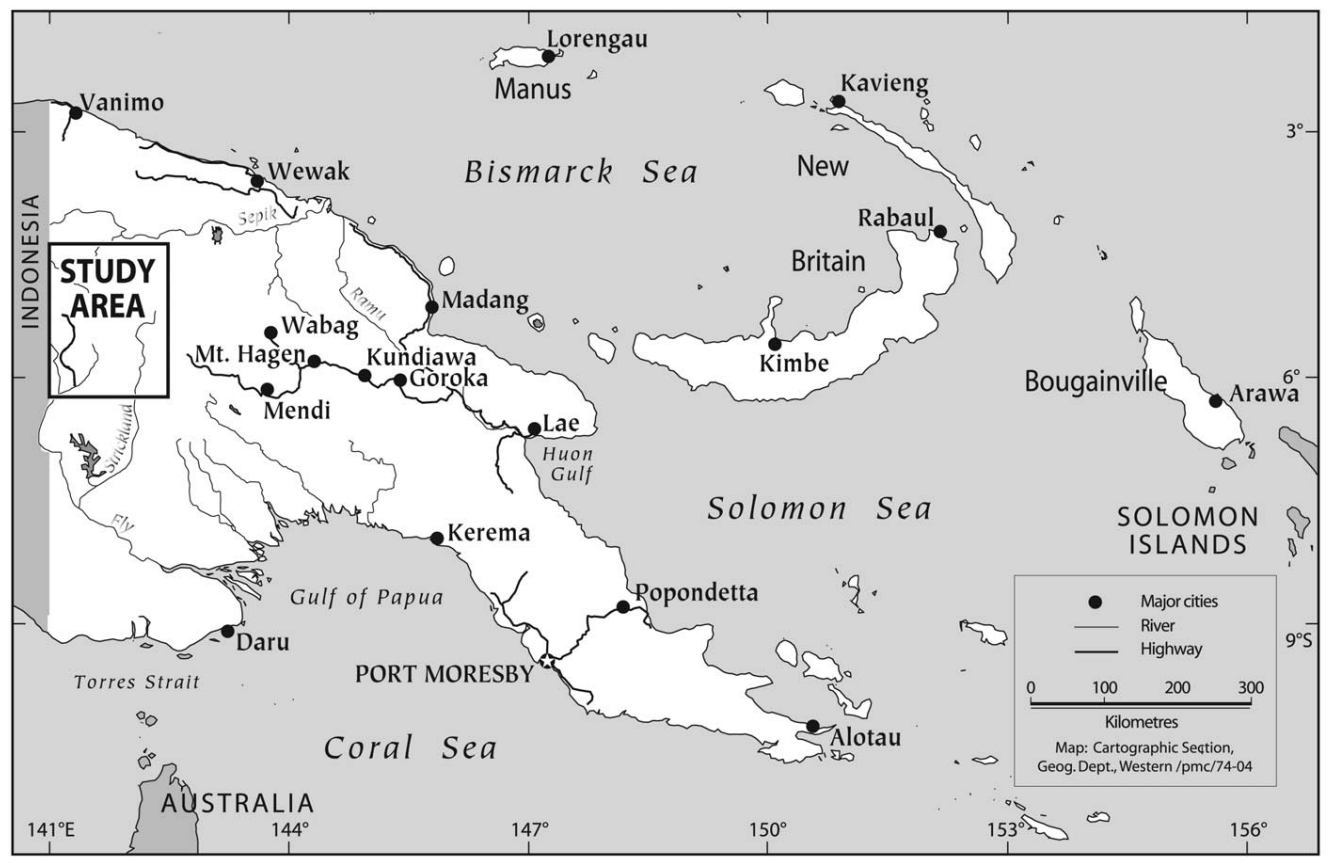

MAP I. Papua New Guinea, showing location of study area 


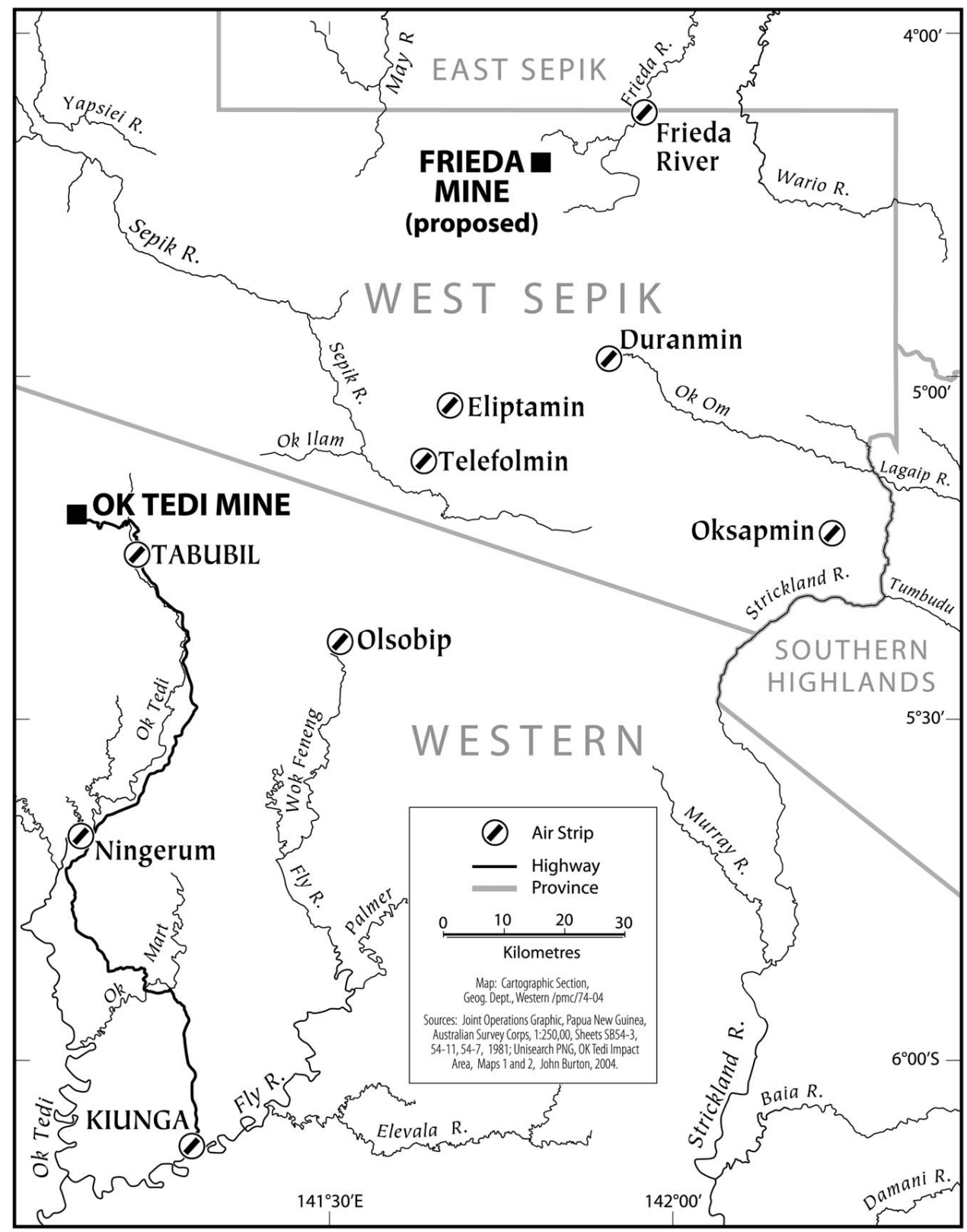

Map 2. The Ok Tedi region 
group to the next, but among those nearest the Ok Tedi site-Wopkaimin, Faiwolmin, Tifalmin, Urapmin, Telefolmin, etc-the prevailing pattern is one of villages of up to 250 or so, along with a system of temporary garden houses in outlying bush. The combined total of Min people in both Western and West Sepik Provinces is approximately 25,000.

The people of the southern foothills and plains are divided into three ethnic groups, the Ningerum, Yonggom, and Awin. Traditional settlements consisted of scattered hamlets and homesteads, but after the Second World War these peoples were encouraged to resettle into villages (population 150 or so) near watercourses, a pattern that persists today. ${ }^{3}$ Traditional livelihoods are based on a combination of sago gathering, hunting, and fishing, with some supplemental gardening. Taken together, this population numbers approximately 20,000 .

Ok Tedi's impact on these populations has been very "lumpy" and uneven over different phases of the mine's history, varying with proximity to the mine and differences in airstrip, river, or road access (see, eg, Blinkoff I998; Jackson 2003; Robbins 1997). Setting aside the situation of the mine site's landowners, the Wopkaimin (Hyndman I997), however, we can broadly distinguish between Ok Tedi's impact in zones corresponding to the general division between the southern downstream groups and Min people living in the mountains. For the most part, Min have been active and enthusiastic participants, mainly as employees at Tabubil and secondarily as beneficiaries of a number of programs directly or indirectly associated with the mine, including vegetable marketing schemes, provision of health and education facilities, and so on. For those most closely associated with the mine-mainly Faiwolmin, Oksapmin, and Telefolmin - mining has figured as the chief source of income for people whose development prospects prior to Ok Tedi were nil.

The story is very different for those living downstream from the mine, however. With the exception of the Ningerum living near Tabubil, relatively few downstream people were employed at Ok Tedi, and whatever local development the mine facilitated tended to be overshadowed by the far more dramatic effects of the massive dumping of mine tailings and waste rock in the Ok Tedi River. By the I99os the lower Ok Tedi had silted up so much that it regularly overflowed its banks and deposited a layer of sterile sand on top of levees that had previously been the most productive garden sites for people living along the river. Side branches and channels became choked with sediment, killing sago stands and up to 480 square kilometers of forest, while the water's constant turbidity drove local fish stocks away (see Kirsch I993; World Bank 2000). 
Both the Yonggom and Awin were affected, albeit to differing degrees. Occupying the land around Kiunga and the east bank of the Ok Tedi, Awin have benefited more from the mine than the Yonggom; many find employment at Kiunga, and a number of villages have relocated from the banks of the Ok Tedi to sites along the Kiunga-Tabubil highway.

Yonggom, by contrast, are in a marginal position with regard to minerelated development (Jackson 2002; King 1997), and damage to their subsistence-based livelihood has been correspondingly devastating as a result. An additional pressure on Yonggom livelihoods was posed by the influx of 5,000-7,000 ethnic Yonggom refugees who fled fighting on the Indonesian side of the border; ${ }^{4}$ the arrival of the refugees coincided with the start of mine production in 1984 (see Jackson I993, I24; Jackson 2003; Kakarere 1993; Kirsch 1993; King 1997, 107-108; Banks 2002b, 53). As a result, Yonggom were the most disadvantaged of any ethnic group in the region by the time Ok Tedi was underway.

After much disputing and maneuvering, the mining consortium (Ok Tedi Mining Limited, or OTML) offered a compensation package and various ameliorative measures in response to local complaints. The Awin initially accepted this offer; the Yonggom, with the assistance of transnational nongovernmental organizations and an Australian law firm, brought a civil suit against the major partner in the consortium (Broken Hill Proprietary, or внр) in the Australian courts instead.

The case became a cause célèbre in the international media, and the upshot was an out-of-court settlement offering the plaintiffs a large financial package and an undertaking to mitigate the environmental damage produced by the mine (see Banks and Ballard I997; Jackson 2003; Kirsch 2002). Broken Hill Proprietary instituted a dredging program along the lower Ok Tedi, but continuing controversy over the state of the river led to pressure, particularly from environmental groups, for early mine closure. $^{5}$

A World Bank report to the government set out dilemmas posed by balancing environmental concerns against social impacts and recommended the formulation of a mine closure policy that made some provision for continuing services and cushioning the inevitable loss to local incomes that would ensue (World Bank 2000). ${ }^{6}$ In 200I, Broken Hill Proprietary exited the consortium and a series of agreements were negotiated between the national government, Ok Tedi Mining Limited, and downstream communities, providing the legal framework for carrying on with mining until approximately 20I0. The BHP majority equity in Ok Tedi Mining Limited ( 52 percent) was transferred to the new PNG Sustainable Develop- 
ment Program (PNGSDP). The program manages its share of OTML dividends with a mandate to use these to support "sustainable development" plans, with a special focus on communities downstream from Ok Tedi (see OTML 2000a, 2000b, 200I; PNGSDP 2003; PNGSDP 2004, 27ff).

This background serves to underscore the variability of relations between different groups of local people and large-scale mining projects: there is no single "community" that is affected, and relations between communities and projects are often shaped by differing degrees of benefit, disadvantage, or disparity (compare Filer 2000; Li I996; Jorgensen I997; Visser 200I). These relations also shift over the lifespan of a project as it moves from construction to closure, a trajectory that is itself affected by feedback from the prevailing state of such relations (see Filer 1990; Gerritsen and Macintyre I99I; Jackson I993). In the case of Ok Tedi, the peak period of employment was during the first three years of the project as mine and town site construction was underway, while various kinds of compensation and amenities tended to materialize only after this time. The impact of downstream damage to the Ok Tedi River, on the other hand, became an international crisis nearly a decade after the mine went into production, and this crisis may fairly be said to have transformed subsequent relations between downstream communities and the project. It is well to keep such things in mind when posing questions about the consequences of mineral projects for indigenous peoples.

\section{Telefolmin and OK Tedi}

Numbering over 4,500 , the Telefolmin hold a preeminent place among Min peoples as the last-born descendents of Afek, the ancestress of the region's population. Afek inaugurated the Telefol world by building the Telefolip, a huge spirit house around which the village of the same name subsequently grew. It is from this house that Telefolmin in turn take their name, and local tradition holds that all Telefolmin are ultimately descended from the village in which the house is located. Containing a number of sacred relics, it was the site for the performance of rituals underwriting taro gardening and warfare. It is an article of faith that the well-being of Telefolmin as a people was bound up with the Telefolip and its continued occupation of the same site, but its significance went beyond the confines of Telefol territory, for the Telefolip rituals were held to affect gardens throughout the Min area, benefiting friend and foe alike.

Although Telefolmin had sporadic contact with Europeans since Rich- 
ard Thurnwald entered the area in I9I4 (Melk-Koch 1989; Champion I932; Gammage I998; Morren I98I), it was not until the Second World War that outside contact became permanent with the establishment of a military airstrip not far from Telefolip. Following the war, military administration passed to civil authorities: a patrol post was established in I948, and Baptist missionaries were permitted into the area in the early I950s.

Despite an influenza epidemic that ravaged the area at the end of the war, Telefolmin were well disposed toward the outsiders during the early days of colonial administration, and the Telefomin station became the headquarters from which administrative influence was extended throughout the region. This period came to a dramatic close in late 1953, when Telefolmin staged coordinated attacks against government patrols and the station, killing two Australian patrol officers and two native policemen (Craig 1990; Quinlivan 1954). Participants were rounded up, tried, and sentenced to jail; the administration, for its part, cautioned government personnel to concentrate on "law and order" and security.

For the remainder of the period until independence (1975), Telefolmin and environs were relegated to the status of remote backwaters. Without roads-or even the possibility of them-the area was entirely dependent on air transport for its connections to the outside world, rendering most of the obvious cash-cropping options hopeless. Instead, young men signed on for two-year plantation labor contracts elsewhere in Papua New Guinea, and this remained the most common source of income during this period. What such forays abroad revealed was the disparity between Telefol backwardness and the relative wealth of coastal (and later, highland) areas. Such perceptions fueled dissatisfaction and the conviction that the government was determined to punish Telefolmin for the events of 1953 .

Despite this gloomy picture, there were bright spots. From the midI96os onward, local administration officers talked increasingly of developmen, and undertook various schemes (sometimes without official sanction) to enhance local prospects. More importantly, during the I960s and I970s mineral exploration got underway in earnest, with attention focused on two promising prospects to the north and south of Telefolmin: Frieda River and Ok Tedi. In these early days a small but significant number of Telefol men were hired to help geological survey crews cut tracks, collect samples, clear helipads, and build camps. The work was hard but congenial (it made use of homegrown skills), the pay was far better than anyone had imagined, and it was located close to home. Mining had acquired a good name in Telefolmin. 
Expectations for mining loomed large on the Telefol scene in the years just before independence, and local hopes for the future rose with announcements and rumors about the imminent launching of mining operations-and fell with news of each delay. Workers at the Mount Isa Mines prospect at Frieda worked through their lunch hours on the strength of the assurance that they were working to build "their mine" (Don Gardner, pers comm I995), while Kennecott maintained two camps at Tifalmin and Tabubil. Although the Frieda operation was scaled back after initially disappointing results, there was much talk about Kennecott's Ok Tedi prospect. By the mid-I970s, however, Kennecott had abandoned their Tifalmin camp and reduced Tabubil's staff to a skeleton crew. Through a combination of radio news reports, government announcements, and informal statements by mine staff, local people learned that the holdup was somehow linked to negotiations surrounding PNG independence (see Jackson 1982). When it became clear that things had halted because of an impasse between Kennecott and the new PNG government, resentment became intense.

With the arrival of independence, Telefolmin secured electoral representation in Port Moresby, where one of the main concerns was to oversee the inauguration of mining. At roughly the same time, a local movement known as Rebaibal resulted in the wholesale conversion of the overwhelming majority of Telefolmin to Christianity. As far as most Telefolmin were concerned, a new and sought-after era had begun (see Jorgensen I98I).

\section{The Mine and the New Prosperity ...}

Shortly after independence the new government reopened the question of developing Ok Tedi and concluded an agreement with a new consortium (in which it became a partner) to get mining underway. By the mid-I980s Telefolmin became participants in Papua New Guinea's minerals boom with an enthusiasm on a par with their embrace of evangelical Christianity. At the peak of employment in Ok Tedi's construction phase (I98II983), Telefol men poured into Tabubil. This was especially true for those villages near the government station or at the head of the Eliptaman Valley, with airstrips connecting them to Tabubil: as many as 40 percent of the men of these villages got jobs whose wages compared favorably with those of school teachers and public servants. In a matter of only a couple of years, Telefolmin had gone from being a forgotten corner of the West 
Sepik to one of the wealthiest rural areas in the country. In subsequent years individual Telefolmin prospered further as entrepreneurs in spin-off developments or as village storekeepers who got in on the action by busily supplying their neighbors with commodities ranging from biscuits, beer, and frozen chickens to radios and Adidas sportswear. Before long, Telefol villages experienced a building boom as newly trained carpenters used their skills to build houses out of sawn timber with corrugated iron roofs and glass windows. Local business groups matched this with stores equipped with freezers and electrical generators, snooker tables, haus kaikai (eating houses), and at least one video parlor along the government vehicle track near the mission station, a strip that became known as taun. New consumption styles gave Telefolmin the sense that, for the first time, they were enjoying the benefits of developmen, ushering in participation in a local form of modernity (compare Golub, this issue). As one man remarked, after Ok Tedi, it seemed that "the only people without cash were babies in their mothers' bellies."

The presence of so much money and the absence of so many men could not help but reshape village life. Parents and wives gardened and tended pigs for absent sons and husbands; women's subsistence burden increased appreciably, with significant effects on local production. In addition to their usual gardening tasks, women undertook to clear plots for gardens (work previously done only by men), while adjusting their routines by planting more cassava and less taro. Labor savings were accomplished by shifting the majority of gardens to tracts located nearer village sites than had previously been the case, cutting down on travel time to the bush. These measures sufficed to support a sharp increase in pig production, which doubled despite an apparent labor shortage, and many women found time enough to earn independent cash incomes by planting vegetables to be marketed for the Ok Tedi commissary. Few complained, and some even seemed to relish their assumption of previously masculine tasks, epitomized by a handful who went so far as to kill pigs on their own and beat drums to celebrate the fact.

The influx of wealth prompted a number of shifts in patterns of exchange and circulation. Although reciprocal exchange always played a very attenuated role in Min cultures when compared with highlands populations east of the Strickland (Ipili, Enga, Hagen, etc), Telefolmin had traditionally held periodic intervillage feasts known as atool. In atool, guests from one village would "come to dance" for a host village and be feasted with pork. Sometime afterward, the tables would be turned as the erst- 
while hosts became guests at a reciprocal dance feast. Such affairs never involved the slaughter of very many pigs, but they were sufficiently frequent that the word atool provides the Telefol gloss for "year." In the years since Ok Tedi got underway, intervillage dance feasts gave way to feasts staged for workers returning on Christmas leave-new atool-in which pigs were slaughtered in their name; in return, they were expected to provide appropriate cash countergifts. At intervillage atool in the mid-I970s one or two pigs was considered about right; at post-Ok Tedi atool in the I980s and I990s even relatively small villages could muster a score of pigs at Christmas. The demand for cash goes a long way toward explaining the intensification of pig husbandry at the same time that available garden labor declined.

More far-reaching shifts were evident in the role of cash in marriage arrangements after Ok Tedi. In common with a number of other Min peoples, Telefolmin had a strong preference for village endogamy built around the principle of sister-exchange. Although bridewealth was a feature of the system, it played a secondary role in relation to the overall goal of ensuring that there was an equivalence or balance of women received for women given in marriage. The payment of bridewealth-principally made up of shells and stone adzes-never extinguished a debt in women, and the payment was meant to be balanced by an equivalent payment of pork from the bride's parents. During the I960s, this system had undergone change largely as a result of the introduction of plantation labor and the propensity of young Telefol women to seek matches with administration employees from other parts of the country. Both factors led to an increasing monetization of bridewealth, as young men used cash to free themselves from dependence on their elders and as parents demanded cash to deter outsiders from marrying their daughters. All of these changes were already in place before the advent of Ok Tedi. However, Ok Tedi radically altered the orders of magnitude involved: average bridewealth payments in the I970s were little more than roo kina (US\$80 at that time), but by the mid-I980s the figure had risen to nearly ten times that amount and was soon to go much higher, with some transactions exceeding I0,000 kina (US\$I0,000; see Jorgensen I993).

Villagers' enthusiasm for Ok Tedi was matched by the eagerness of men-mostly young - to work there and sample the attractions of life at Tabubil. Though the work was tough and demanding, workers enjoyed a new and relatively opulent lifestyle. Housed in dormitories equipped with showers, clean beds, and toilet facilities, they enjoyed a standard of 
accommodation otherwise known only from rumors about city hotels. Meals always included meat and as much food as one could eat, and afterhours activities centered on the canteen and its bar. Sundays were spent in impromptu sports matches or barbecues. All in all, with money in their pockets and fun to be had, most reckoned it was a good life.

Things were not entirely carefree, however, for this lifestyle came with strings attached. Relatives would routinely make visits to Tabubil to see kin working there, and many young men found themselves obliged to act as hosts whose generosity or lack of it would be remarked on back home. Many complained about the seemingly endless stream of visitors and agitated with the mine management to undertake measures to curtail this traffic. Workers also received letters from home, and an obligatory component of such letters was a request for cash for some purpose or another. The workers were becoming acquainted with the terms of a new remittance economy.

\section{... AND AMBivalenCE}

Despite the general air of optimism that accompanied the prosperity Ok Tedi brought, the situation produced a number of problems associated with the flow of wealth from workers to villagers. One area of difficulty was conflict over claims to workers' remittances, particularly in the case of men who had the expectations of both wives and parents to satisfy. Villagers' demands came to a head during the annual Christmas furloughs, with the expectation that visiting workers would be generous in passing out banknotes to all and sundry.

Ok Tedi's construction phase was over by 1984, and from that point on a number of former workers returned to find the transition to the village difficult. Village life seemed cramped and drab after their time at Tabubil, and some preferred to hang out around the trade stores near the station. Often they came with fewer savings than they would have liked, and their return was again greeted with expectations of liberality. If they were single, their position was made critical by skyrocketing bridewealth demands. Some were able to marry and meet their affines' expectations, but others found themselves wondering how they could possibly find a wife. One strategy was to call on friends still working at the mine for contributions; others despaired of marrying and departed for towns on the coast in search of work. One man worked diligently as an unpaid clerk in a relative's trade store in the vain hope that his industry would secure 
him an offer of a wife. For at least some young men, the solution was to seek wives from outlying areas such as Atbalmin, where monetary expectations were lower (Jorgensen I993; compare Polier 1996).

Against this background it is not surprising to find that some Telefolmin are ambivalent about the mining economy and its consequences. Among villagers near the government station, for example, the Seventh-Day Adventists (SDA) made significant inroads beginning in the early I990s. Promoted by Papua New Guinean evangelists, the SDA message attracted strong support among men returned from work at Tabubil, notably including some who had difficulty marrying. The local SDA program discourages the payment of bridewealth and forbids the keeping or consumption of pigs. This has effectively removed SDA members from the local nexus of cash exchanges involving bridewealth and pig-killing, thus obviating two troublesome aspects of the relationship between former workers and other villagers (compare Boyd I985, 200I). ${ }^{7}$

Other signs of ambivalence became evident in incidents involving novel encounters with Magalim, the bush spirit (masalai in Tok Pisin-see Jorgensen 1980; 1998), who was increasingly identified by English-speakers as an "evil spirit" (tebel nogut in Tok Pisin) or Satan. Traditionally associated with river courses, mountaintops, and the bush in general, Magalim was understood as the master of wild things beyond human control. While always powerful, Magalim was generally seen as a source of danger, and best avoided. Not so much hostile as indifferent to human aims, Magalim came most readily to mind when things went wrong. Since Ok Tedi got underway, people came to see Magalim's hand in events associated with the mine and mining. When attempts to construct a tailings dam at Ok Tedi were wiped out by massive landslides (Jackson I993), for example, this was said to be the work of Magalim, who causes earthquakes, slides, and flooding. Workers at Ok Tedi reported seeing him near the mine site in the guise of a huge speckled python-one of his favorite forms - and suggested that he might be responsible for industrial accidents at the mine. Workers also reported that he appeared in the workers' canteen at Tabubil, where he assumed the form of a suspiciously generous European who was offering to buy workers drinks.

More arresting from a Telefol point of view was that encounters with Magalim increasingly took place in the environs of villages. Most of these incidents coincided with the return of workers to their home villages at Christmas. In one case, Magalim frequented stream crossings near a village, where he assumed the frightening shape of a tall headless European 
wearing black trousers and a white shirt. In another incident, he attempted to enter the house of a woman whose husband was working at Ok Tedi and took the form of a tall European with four glowing eyes. Significantly, his attire included the distinctive yellow boots worn by Ok Tedi workers.

Taken together, the association of Magalim with the mine and mine workers (as well as Europeans) is suggestive: no longer content to lurk in the deep bush, Magalim now impinges on Telefolmin at precisely those points marking the intersection between village life and the mining economy. This suggests that villagers are uncomfortably aware of the precariousness of their position along a frontier zone of powers that may provide wealth but are indifferent to their fate. In response, practices associated with local forms of Christianity have taken on a new and prophylactic dimension. In Telefol villages near the Frieda/Nena mining prospect (Jorgensen 1997), where exploratory drilling has been going on for decades, Magalim-like "evil spirits" are held to be encroaching on villages from the bush, causing illness in the process. A protective cordon of small crosses at the entrance to villages, at stream crossings, and at the margins of the bush is meant to bar the way to such spirits and has been a routine feature since the mid-I990s (compare Lohmann 2000, 264, 322). This practice has now spread to other Telefolmin: in the home valley of Ifitaman, small crosses are planted around the margins of the airstrip near Telefomin station-the major link between rural Telefolmin and Ok Tedi.

\section{Mining, Marginality, and Ancestral Travels}

The encroachments of Magalim and "evil spirits" may be taken as an index of the sense of vulnerability that accompanies engagement in the mining economy, and it is not too much to suggest that one component of this may be the fact that villagers have for the most part been dependent on the uncertain commitments of young men for remittances. But Telefolmin also envision a different kind of relation to $\mathrm{Ok}$ Tedi and other mining projects, one in which their share is more than just workers' wages.

Ok Tedi's ore body is located at Mt Fubilan, and when initial plans for the mine were announced, Telefolmin were unsurprised that this should be the site of wealth dug out of the ground. Situated astride Afek's track between Telefolip and the Wopkai ritual center of Bultem, Mt Fubilan is located above the traditional Land of the Dead (Bagelam). Telefol myth 
explains how Afek killed her younger brother, Umoim, and then sent him underground to prepare a land for the dead in the west. There he created the stone adzes (fubi) after which the mountain is named, and the shell valuables (bonang) Telefolmin used in bridewealth and mortuary payments, which originated from maggots in his decaying flesh (see Jorgensen 1985). Thus Bagelam is not only where Telefolmin went after death, but it was also held to be the source of wealth (compare Halvaksz, this issue).

When mining began at Fubilan at the start of the I980s, Telefolmin understood the mineral wealth extracted from the mountain to be a transmuted form of the wealth created by their ancestors, and on this basis laid claim to rights in relation to the mine site. Although Telefolmin were not recognized as landowners of the site-much to their resentment and consternation-they succeeded in gaining recognition for their claims in the form of the Telefomin District Development Agreement, which provided a package of benefits including a new high school in Telefolmin, along with I million kina (then worth about US\$ I million) in annual development funds earmarked for the area. The seal on this agreement was set when the PNG governor general came to Telefolmin for the signing; he was presented with a fubi adze by the councilor from Telefolip, the village from which Umoim had set forth. In local eyes, this amounted to government acknowledgement of the ancestors and an admission of the truth of the myths on which Telefol claims were based (Jorgensen I990). ${ }^{8}$

Since that time mineral exploration in the region has continued apace, and at the start of the I990s the renewed possibility of a mining project north of Telefolmin in the Frieda River valley (Nenataman) was announced. Telefolmin have vigorously pressed their claims to rights to the site-which is near a frontier between four major ethnic groups-with reference to myths along lines reminiscent of the story of Umoim and the claim to Fubilan. The Nena deposit is located near a quarry for a particular kind of adze (bangelii), and the source of these adzes is said to be human bones planted there by an ancestor from Telefolip (see above; Jorgensen 1997).

These myths, and others like them, do more than serve an instrumental purpose in staking claims to mining benefits. The emphasis on ancestral journeys acts as a counter to the ways in which Magalim encroaches on Telefol lives by claiming Telefolmin (and Telefolip) to be central, rather than merely peripheral, to the regional mining economy (see also Biersack I999; Jacka 200Ib; Wardlow 200I). Such issues matter greatly to Telefolmin, and the risks of marginalization are serious and real. Some of the 
more extreme cases of marginalization produced by mining become evident when we consider communities outside the main flow of cash from Ok Tedi. One such case is afforded by Mantaman.

A small Telefol village located in a side valley off the Ok Fak, Mantaman is, in traditional terms, a good place to live. Located in mid-montane rain forest, its garden lands are fertile, domestic pigs do well, and the surrounding bush abounds in game and other wild resources. Highly prized oil pandanus is particularly abundant there, and when I visited the village in the mid-I99os there was an impromptu pandanus feast that would have been the envy of Telefolmin anywhere. Although a model of subsistence affluence, Mantaman is a village in trouble. It has no ready access to an airstrip, and none of its men have succeeded in finding employment at Ok Tedi. It has only half as many women as men, and the surfeit of unmarried men (and attendant fears of adultery) is one reason why villagers insisted on retaining a men's house despite being fervent Christians. A number of women have left to marry into less remote villages, and with only a handful of young girls remaining as prospective wives, it is clear that the people of Mantaman have to attract women from elsewhere in order to survive. This, however, is just what they are unable to do. Tucked away in their corner of the Fak valley, they are too remote to take part in the regional mining boom, and without the money that mining brings, they cannot hope to raise the bridewealth they need to get wives. As a result, the village's future seems in doubt.

Mantaman's predicament is the result of its marginal position on the mining frontier, a fact of which villagers are well aware, and this misfortune has become something of a local obsession. Conversations with local people turn quickly to what is uppermost in their minds: subterranean "gold" (gol) located on their land. The village luluai (a now-defunct government title) made a lengthy and earnest plea for a team of geologists to be sent to his village so that people could lead them to a series of caves near the headwaters of their valley. Smoke or mist issues from these caves, and the voices of subterranean men can be heard there as well. This, local people are convinced, indicates that their land is sure to be full of gold and a good place for a mine-if only some geologists would come with their instruments to see it.

For the people of Mantaman, as for other Telefolmin, it is clear that mines are at the center of all the things associated with developmen, and to be far from mines is to be exiled to the margins. This has been particularly so since the mid-I980s, when people witnessed the beginnings of the national government's prolonged retreat from rural areas at the same 
time that mining projects seemed to spring up everywhere. During the early I990s, there was talk of mines throughout Papua New Guinea-not only at Ok Tedi, or possibly at Frieda/Nena, but also at Porgera, Mt Kare, and various other places as well. By the mid-I990s a myth was in circulation that accounted for the existence of several different mineral deposits in terms of the actions of ancestors from Telefolip, who had seeded the landscape with gold. All the mines in the western part of the country-Ok Tedi, Frieda/Nena, Porgera-were connected to Telefolip as the parts of a body. The proposed Frieda/Nena mine was a leg, the Porgera mine in Enga Province was the other leg, and Ok Tedi was the head. Just as Umoim had created the stone adzes (fubi) that were the source of Ok Tedi's gold, so too had he placed stone adzes of distinctive kinds at Frieda/Nena (bangelii) and at Porgera (mook). All of these mines are located just at or beyond the boundaries of Telefol territory; according to the myth, however, the heart is at Telefolip, and this is the ultimate source of all the mineral wealth in the region.

\section{From Taro Cult to Mining Cult}

At Telefolip-in the enclosure of the spirit house that gives the village and the Telefol people their name-there is a perforated stone disk (tingii). This, local people say, was the prototype - the original — of the one-kina PNG coin, also a perforated disk. This was the heart of the gold and the true source of all money. The reason that no mining has taken place at Telefolip is that this stone disk covered the hole in which Christ's cross stood at the crucifixion-the same hole that served as the entrance to the road to the Land of the Dead. It was feared that tampering with this would bring about the end of the world, and senior men at Telefolip carefully concealed the significance of the tingii from outsiders in order to prevent this taking place (Jorgensen 200I).

The myth of where gold comes from is widely known throughout Telefolmin, and offered to resolve a mystery that many found troubling: the fact that no gold has been found in the vicinity of Telefolip, the center of the Telefol world. At the same time, it affirmed that, as with Ok Tedi, Telefol claims to a share of mining wealth amounted to no more than a claim to recover what was always theirs. This refused marginalization by reasserting the centrality of Telefolip-and the Telefolmin people-on Papua New Guinea's western mining frontier.

The tension between Telefol marginality and the Telefol sense that everything begins and ends with Telefolip has intensified over the last sev- 
eral years. These days all the talk is about Ok Tedi's scheduled closure in 20I0, raising new questions about Telefol futures. Telefolmin know well enough that, unlike the Wopkaimin landowners, they have no trust funds to look after them when the mine goes, and that when the mine shuts down the work it has provided will be gone (see also Imbun, this issue).

It is perhaps in this light that we should understand what happened in 2000, when the Telefolip spirit house collapsed after having stood for a quarter of a century. Rather than rebuilding it as tradition demanded, in 2002 the villagers of Telefolip took part in a charismatic movementknown as "Operation Joshua"-prompted by the intervention of an expatriate evangelist and his companion, who was identified as a geologist. Spurred on by the belief that satellite photos revealed the presence of "diamonds and gold" beneath the spirit house site, and encouraged to clear traditional spirits away as a means of promoting development, the villagers at Telefolip sought another source of minerals on their home ground. ${ }^{9}$ They burned the spirit house's relics and excavated the site in search of the wealth it was believed to conceal. Although strongly opposed by Christian Telefolmin from other villages (who argued that their "culture and history" were being destroyed), they were undeterred-nor did they let the failure to find either gold or diamonds discourage them. After digging some meters down, they found discolored earth that reportedly gave off a powerful smell, which they attributed to a dangerous kind of "uranium gas." In the meantime, they sent out messages to all and sundry —including myself-asking (like the villagers of Mantaman) for geologists to be sent to inspect the site. Hopes for the development of this gas deposit are high, and at the time of writing the villagers of Telefolip await the arrival of a European missionary-cum-geologist to help get a project underway at Telefolip. Operation Joshua attempted to reclaim the centrality of Telefolip, but as the center of a mining cult rather than a taro cult.

\section{Conclusion}

Assessing the impact of the Ok Tedi project on Telefolmin is no simple matter: mining has played out differently for different people and has been variable in its effects over time. For most, the incomes that mine employment brought have been welcome and have opened possibilities otherwise unavailable to people living in remote rural areas. Many Telefolmin now enjoy a lifestyle that compares favorably with that of people living in PNG towns, and they do so without running the risks of sudden poverty and 
rising criminality that have come to characterize life in places like Port Moresby or Lae. This is true even in Tabubil, which is free of the ubiquitous razor wire that signals the insecurity of urban life elsewhere in the country. Beyond this, there is a sense of connection with the rest of the world that has come to be associated with modernity: young people enjoy a sense of fashion and style, people watch television, graduates of the high school have gone on to take university degrees in Papua New Guinea and abroad, some have developed work or business contacts outside the area, and yet others have seen the sights of Sydney, Singapore, Seville, and Jerusalem.

As we have seen, however, these possibilities and the wealth that enables them are not there for everybody. Villagers-especially women and older people-have been continually faced with the problem of staking their claims to workers' wages, and not all are equally successful. For their part, workers at Tabubil have continually been caught in dilemmas that call on them to weigh villagers' expectations against their own desires. There is a certain precariousness in this situation, which makes villagers dependent on the mine and on workers not fully under their control, and I have argued that an uneasiness about this is registered in sightings of Magalim or fears of evil spirits encroaching on Telefol villages.

With the announcement that Ok Tedi will be shut down, however, questions facing Telefolmin have shifted: the issues no longer merely concern how to manage the incomes produced by Ok Tedi, but have instead become focused on how to deal with the end of mining. For its part, Ok Tedi Mining Limited is currently formulating plans to ease the transition to mine closure (OTML 200ob). The programs announced for the Min living north of the mine, however, do not include "community trusts" with funds for local development projects. Instead, Telefolmin-excluded from such benefit streams by virtue of the fact that their lands were not damaged by Ok Tedi's operations-will be the recipients of projects directed toward food security. The aim of such plans seems to be to facilitate a return to subsistence livelihoods by enhancing local crop production and helping with small livestock projects.

While these plans are well intentioned, it seems unlikely that Telefolmin and their Min neighbors will view them as anything more than a poor substitute for a lifestyle supported by cash incomes over the last generation. Whatever else is the case, village life for Telefolmin is not simply a rural haven where people can live out an unencumbered subsistence lifestyle in traditional terms. Leaving aside people's fondness for store-bought food and clothing, money has become a necessity for everything from mar- 
riage arrangements and the conduct of village ceremonies to the payment of ever-higher school fees.

Those who, like the villagers of Mantaman, are far removed from direct engagement with Ok Tedi find that subsistence affluence is not enough. They are not so much insulated from the cash economy as missing out on it, with consequences that can place the continued viability of their communities in jeopardy. As the destruction of the Telefolip spirit house shows, for Telefolmin there is no going back to "the way things were before." Excavating the ground beneath the spirit house was an irreversible step, and in doing so villagers at Telefolip made clear that growing taro- the house's raison d'être-is no longer sufficient. Local visions of the future are predicated on continued access to cash.

As the Ok Tedi mine winds down, the way forward for Telefolmin is anything but clear. While devotees of Operation Joshua put their faith in the prospect of a mine on the site of the old spirit house, other Telefolmin are no less fervent in their hopes that the long-mooted mine at Frieda/ Nena will get underway in time to take up the slack when Ok Tedi closes. Still others experiment with vanilla growing, the star of the latest PNG agricultural boom. However these things work out, stubborn questions will remain. Will bridewealth be scaled back, or is it possible-as has happened in other areas (compare Zimmer-Tamakoshi 1993) — that young men will be obliged to migrate to towns outside the area in search of work if they hope to meet affines' expectations? What is to become of the air connections Telefolmin currently enjoy-and the reduced costs for consumer goods they enable? What of services? Will the local hospital or high school, currently supported with funds from Ok Tedi, be maintained in the aftermath of closure?

To these questions facing rural villagers, there are others that may apply with particular pointedness for Telefolmin who have made Tabubil their home. There is now a cohort of young Telefolmin in Tabubil who have spent their childhood and most of their youth in town. Although those involved in planning mine closure clearly expect to see much of Tabubil's and Kiunga's population return to a subsistence-based village lifestyle (see, eg, OTML 2000b, I4-I6), such moves may be less a homecoming than displacement. As James Ferguson has shown for mine workers in Zambia (I999), returning to village life is not invariably smooth or happy, and many may choose to try their luck in some other urban niche, even if it means moving to the less-than-hospitable setting of towns like Port Moresby.

Ok Tedi's impending closure poses more than just questions about live- 
lihoods, however, and raises issues concerning the meaning of recent Telefol historical experience. Much of our thinking - and that of those on the margins of globalization-imagines modernity as an achievement that constitutes an arrival at some historical endpoint. For those affected by Ok Tedi, however, it is becoming increasingly clear that modernity comes with no guarantee of permanence and that connections with "the modern world" can be broken as easily as they can be made (Ferguson 2002). When the villagers of Telefolip dug up the site of Afek's house the stakes were high, for the question was not merely whether or not they would become mine owners, but whether they would take a place at the center of things or be relegated to the margins. This is a question facing many Min peoples, from the Miyanmin who are still "chasing after modernity" (Blinkoff I998) to the Urapmin, whose sense of being in "Last New Guinea"-the remotest of the remote (Robbins 1997)-offers millenarian Christianity as the only clear alternative to participation in the mining boom.

When Papua New Guinea charted its course for mining policy following independence, the vision was that the state's deployment of mining revenues would foster broad-based development across the country. While it is difficult (and perhaps pointless) to imagine what things might have looked like without the revenues mining produced, it is fair to say that the promise of broad national development based on these revenues remains largely unfulfilled. To the extent that mining has brought clear and visible development, it has done so mainly at a regional level, in the hinterlands of such projects. But as the Ok Tedi case shows, although mining has opened up the possibility of entry into modernity for at least some of the people living on the minerals frontier, this modernity may prove more transitory than anyone expects. The implications for PNG mining communities are large, since Ok Tedi is only one of several mines slated for closure: the Misima mine in Milne Bay Province has recently closed and the Porgera mine in Enga Province will be shutting down by the end of the decade. The pressing questions for local people and those who would understand them may now turn on understanding what comes after mining has departed the scene and the experiences of modernity become memories of the past.

THIS ARTICLE DRAWS ON research between 1974 and 2004 supported by a number of agencies, including the Social Sciences and Humanities Research Council of Canada. It also benefits from conversation and correspondence with colleagues 
and friends over the years, including Glenn Banks, Aletta Biersack, John Burton, Barry Craig, Colin Filer, Tony Friend, Don Gardner, Alex Golub, Jerry Jacka, Stuart Kirsch, Martha Macintyre, Joel Robbins, Paige West, and Mark Winfield. Numerous people in Telefolmin have been helpful, and here I would especially like to acknowledge Uunsep Kesilimengim, Stan Tinamnok, Beksep Dagayok, Yon Dagayok, Robert Dripal, Dagasim Binengim, the late Levi Binengim, the late Wesani Iwoksim, Piamnok Lakurengim, Silas Neksep, and Bumanok Wanamsep. Information pertaining to some events in Telefolmin is derived from letters and telephone conversations with Telefol friends-especially James Nifinim of the Baptist Church, Tabubil-and correspondence with travelers through the region. Barry Craig of the South Australian Museum also provided information based on recent visits to the area. My most recent information is based on visits made to Telefolmin, Tabubil, and Kiunga in mid-2004. Finally, I would like to thank two anonymous reviewers for useful suggestions. The maps were produced by Patricia Connor of the Cartographic Section at the University of Western Ontario.

\section{Notes}

I Kiunga rivaled Daru as the de facto administrative center of Western Province since its dramatic expansion in the late I980s. At present, most of the offices of the Western (or Fly River) Provincial Government operate out of Kiunga, which is occasionally referred to as the provincial headquarters or capital, a title that Daru apparently retains de jure (see, eg, PNG Post-Courier 2005).

2 Robert Welsch drew a similar contrast between the mountain people and those downstream from the project based on different expectations of benefits and outcomes (1982b). Other peoples east of the Strickland occupy a marginal position in relation to both the Ok Tedi and the Porgera mines (Stürzenhofecker 1994; Haley 2002; Stewart and Strathern 2002), and they experience this marginality as a powerful effect of these projects. For accounts of those in the downstream reaches of the Fly River zone, see Burton 1995, Dundon 2002, and Lawrence 1995 .

3 Exceptions to this pattern are many Awin villages along the lower Ok Tedi, which have relocated to sites along the Kiunga-Tabubil highway (Allen and others 1993; Burton I993; Jackson 2003). For ethnographic information on the Ningerum, see Welsch I982a and 1982b; for Yonggom, see Kirsch I991; for Awin and Ningerum, see Burton 1993.

4 These numbers are not included in the population figures cited. Non-Yonggom refugees also crossed into Papua New Guinea during the same period, and many of these people were relocated to the East Awin refugee camp, where a number remain in strained circumstances (see Kakarere I993; Glazebrook 200I).

5 As Stuart Kirsch made clear (I997), the Yonggom plaintiffs themselves had diverse views. There was considerable sentiment in favor of closure prior to the 
settlement, but others said they did not want the mine to close. After the settlement, erstwhile plaintiffs did not favor closure of the mine (Kirsch 2002).

6 During the I980s the Western Provincial Government enjoyed the highest per capita funding in the country as a result of revenue from Ok Tedi, which currently accounts for more than half of all provincial funds (Jackson 2003, 8; see also Krau 2004; PNG Post-Courier 2004).

7 Since I988, when a strike led to the establishment of family housing for married workers, a number of Telefol families have resided permanently in Tabubil (see Jackson 1993, I87). Although the problems surrounding the payment of brideprice do not apply to such workers, who tend to be older and well established, they too are expected to offer hospitality to villagers. Some workers have formed village-based "family groups" in order to organize contributions to village projects, and it is recognized in both the villages and in town that such participation serves to secure workers' continued village membership (and with it, rights in land and a place to return when employment is finished).

8 In the late I990s, the Telefomin District Development Agreement fell victim to program cuts: all payments were suspended and the government subsequently refused to renew the agreement.

9 Millennial expectations often accompany mining projects (as the contributions by West and Golub in this issue attest), though whether they are caused by mining activities is an entirely different matter (see Kirsch I99I). Operation Joshua extends beyond Telefolmin and is part of a larger Pentecostal-charismatic effort in Papua New Guinea (CMDF 2004; see Gibbs 2004). For these and other reasons, an adequate analysis of Operation Joshua would have to attend to strong extralocal linkages that, in fact, are a leitmotif of the movement and central to its operations (see Robbins 2004). I address these issues more directly in another publication (Jorgensen 2005).

\section{References}

Allen, B, R L Hide, R M Bourke, W Akus, D Fritsch, R Grau, G Ling, E Lowes I993 Agricultural Systems of Papua New Guinea, Working Paper No. 4: Western Province. Canberra: Australian National University; Port Moresby: Papua New Guinea Department of Agriculture and Livestock.

Banks, Glenn

2002a Papua New Guinea Baseline Study. London: International Institute for Environment and Development.

2002b Mining and the Environment in Melanesia: Contemporary Debates Reviewed. The Contemporary Pacific I4:39-68.

Banks, Glenn, and Chris Ballard, editors

1997 The Ok Tedi Settlement: Issues, Outcomes and Implications. Pacific 
Policy Paper 27. Canberra: Resource Management in Asia-Pacific and National Centre for Development Studies, Australian National University.

Biersack, Aletta

1999 The Mt Kare Python and His Gold: Totemism and Ecology in the Papua New Guinea Highlands. American Anthropologist Iог:68-87.

Blinkoff, Belinda

I998 A Tale of Two Airstrips: Modernity and Desire in Sokamin, Papua New Guinea. Paper presented at the annual meetings of the American Anthropological Association, Philadelphia.

Boyd, David J

I985 The Commercialisation of Ritual in the Eastern Highlands of Papua New Guinea. Man 20:325-340.

200 I Life Without Pigs: Recent Subsistence Changes among the Irakia Awa, Papua New Guinea. Human Ecology 29 (3): 259-282.

Brown, Paula, and Anton Ploeg, editors

I997 Change and Conflict in Papua New Guinea Land and Resource Rights. Special issue of Anthropological Forum 7 (4).

Burton, John

I993 Development in the North Fly and Ningerum-Awin Area Study. Ok-Fly Social Monitoring Report 6. Waigani, PNG: Unisearch PNG Pty Ltd. $<$ http://rspas.anu.edu.au/rmap/projects/Ok-Fly_social_monitoring/> [accessed 20 March 2005]

1995 Middle Fly and North Morehead Area Study. Ok-Fly Social Monitoring Report No. IO. Waigani, PNG: Unisearch PNG Pty Ltd. <http:// rspas.anu.edu.au/rmap/projects/Ok-Fly_social_monitoring/> [accessed 20 March 2005]

Champion, Ivan

1932 Across New Guinea from the Fly to the Sepik. London: Constable. CMDF, Christian Medical-Dental Fellowship of Singapore

2004 Off TANgent: Medical Missions With a Different Slant-Introducing the Doctor-Pilot-Preacher-Missionary . . < <ttp://www.cmdf-singapore .org/Resources/Off\% 20TANgent.htm> [accessed to Sept 2004]

Connell, John, and Richard Howitt, editors

I99I Mining and Indigenous Peoples in Australasia. Sydney: Sydney University Press.

Craig, Barry

I990 The Telefomin Murders: Whose Myth? In The Children of Afek: Tradition and Change among the Mountain Ok of Central New Guinea, edited by Barry Craig and David Hyndman, I I 5-I 50 . Sydney: Oceania Publications. 
Dundon, Alison

2002 Mines and Monsters: A Dialogue on Development in Western Province, Papua New Guinea. The Australian Journal of Anthropology I 3 (2): I39-I 54 .

Ferguson, James

I999 Expectations of Modernity. Berkeley: University of California Press.

2002 Global Disconnect: Abjection and the Aftermath of Modernism. In The Anthropology of Globalization, edited by Jonathan Inda and Renato Rosaldo, I36-I 53. Oxford: Blackwell.

Filer, Colin

I990 The Bougainville Rebellion, the Mining Industry and the Process of Social Disintegration in Papua New Guinea. Canberra Anthropology I3 (I): I-39.

I997a Compensation, Rent and Power in Papua New Guinea. In Toft I997, I 56-I90.

I997b Resource Rents: Distribution and Sustainability. In Papua New Guinea: A 20/20 Vision, edited by Ila Temu, 222-260. Canberra: National Centre for Development Studies, Research School of Pacific and Asian Studies, Australian National University.

I998 The Melanesian Way of Menacing the Mining Industry. In Modern Papua New Guinea, edited by Laura Zimmer-Tamakoshi, I47-I77. Kirksville, mo: Thomas Jefferson University Press.

2000 How Can Western Conservationists Talk to Melanesian Landowners about Indigenous Knowledge? Resource Management in Asia-Pacific Working Paper 27. Canberra: Research School of Pacific and Asian Studies, Australian National University.

Filer, Colin, editor

I999 Dilemmas of Development: The Social and Economic Impact of the Porgera Gold Mine, 1989-1994. Canberra: Asia Pacific Press.

Gammage, William

I998 The Sky Travellers: Journeys in New Guinea, I938-1939. Melbourne: Melbourne University Press.

Gerritsen, Rolf, and Martha Macintyre

I99I Dilemmas of Distribution: The Misima Gold Mine, Papua New Guinea. In Connell and Howitt r991, 35-54.

Gibbs, Philip

2004 Politics, Religion, and the Churches: The 2002 Election in Papua New Guinea. State, Society, and Governance in Melanesia Working Paper 2. Canberra: Research School of Pacific and Asian Studies, Australian National University.

Glazebrook, Diana

200I Dwelling in Exile, Perceiving Return: West Papuan Refugees from Irian 
Jaya Living at East Awin in Western Province, Papua New Guinea. PhD dissertation, Australian National University.

Haley, Nicole

2002 Ipakana Yakaia: Mapping Landscapes, Mapping Lives-Contemporary Land Politics among the Duna. PhD dissertation, Australian National University.

Howitt, Richard, John Connell, and Philip Hirsch, editors

I996 Resources, Nations and Indigenous Peoples. Melbourne: Oxford University Press.

Hyndman, David

I997 Changing Relations of Production in the Creation of the Ok Tedi Mining Enclave in Papua New Guinea. Resource Management in AsiaPacific Program Working Paper I I. Canberra: Resource Management in Asia-Pacific Program, Australian National University.

Jacka, Jerry

200ra On the Outside Looking In: Attitudes and Responses of Non-landowners to Mining at Porgera. In Mining in Papua New Guinea: Analysis and Implications, edited by Benedict Imbun and P A McGavin, 45-62. Port Moresby: University of Papua New Guinea Press.

200rb Coca-Cola and Kolo: Land, Ancestors and Development. Anthropology Today I7 (4): $3-8$.

Jackson, Richard

I982 Ok Tedi: The Pot of Gold. Waigani, PNG: Word Publishing.

I993 Cracked Pot or Copper Bottomed Investment? The Development of the Ok Tedi Project, I982-I99I. Townsville: Melanesian Studies Centre, James Cook University.

2002 Capacity Building in Papua New Guinea for Community Maintenance During and After Mine Closure. London: International Institute for Environment and Development.

2003 Muddying the Waters of the Fly: Underlying Issues or Stereotypes? Resource Management in Asia-Pacific Program Working Paper 4I. Canberra: Resource Management in Asia-Pacific Program, Australian National University.

Jorgensen, Dan

I980 What's in a Name: The Meaning of Meaninglessness in Telefolmin. Ethos 8:349-366.

I98I Life on the Fringe: History and Society in Telefolmin. In The Plight of Peripheral People in Papua New Guinea, edited by Robert Gordon, 59-79. Cambridge, mA: Cultural Survival.

I985 Femsep's Last Garden: A Telefol Response to Mortality. In Aging and its Transformations: Moving Toward Death in Pacific Societies, edited 
by Dorothy A Counts and David R Counts, 207-226. New York: University Press of America.

I990 Placing the Past and Moving the Present: Myth and Contemporary History in Telefolmin. Culture ro (2): 47-56.

I993 Money and Marriage in Telefolmin. In The Business of Marriage: Transformations in Oceanic Matrimony, edited by Richard Marksbury, 57-82. Pittsburgh: University of Pittsburgh Press.

1996 Regional History and Ethnic Identity in the Hub of New Guinea: The Emergence of the Min. Oceania 66:189-2 I0.

1997 Who and What is a Landowner? Mythology and Marking the Ground in a Papua New Guinea Mining Project. Anthropological Forum 7 (4): 599-628.

1998 Whose Nature? Invading Bush Spirits, Traveling Ancestors, and Mining in Telefolmin. Social Analysis 42 (3): I00-I I6.

200I History and the Genealogy of Myth in Telefolmin. Paideuma 47: IO3-I 28.

2005 Third Wave Evangelism and the Politics of the Global in Papua New Guinea: Spiritual Warfare and the Recreation of Place in Telefolmin. Oceania $75(3 / 4): 444-46 \mathrm{I}$.

Kakarere, Ian

1993 Question of Refugee Camp Remains Unresolved. The Times of Papua King, David New Guinea 708:I I (29 July).

I997 The Big Polluter and the Constructing of Ok Tedi: Eco-imperialism and Underdevelopment along the Ok Tedi and Fly Rivers of Papua New Guinea. In Banks and Ballard I997, I I 8-I40.

Kirsch, Stuart

I99I The Yonggom of New Guinea: An Ethnography of Sorcery, Magic and Ritual. PhD dissertation, University of Pennsylvania.

I993 The Yonggom, the Refugee Camps along the Border, and the Impact of the Ok Tedi Mine. Research in Melanesia I3:30-6I.

1997 Is Ok Tedi a Precedent? Implications of the Lawsuit. In Banks and Ballard 1997, 94-II2.

2002 Anthropology and Advocacy: A Case Study of the Campaign against the Ok Tedi Mine. Critique of Anthropology 22:175-200.

Krau, Dominic

2004 Revised Ok Tedi Pact Signing Today. The National online edition, 29 October. <http://www.thenational.com.pg/I029/nation7.htm> [accessed 29 Oct 2004]

Lawrence, David

I995 Lower Fly Area Study: "You Can’t Buy Another Life from a Store." 
Ok-Fly Social Monitoring Report 9. Waigani, PNG: Unisearch PNG Pty Ltd. <http://rspas.anu.edu.au/rmap/projects/Ok-Fly_social_ monitoring/> [accessed 20 March 2005]

Li, Tania Murray

I996 Images of Community: Discourse and Strategy in Property Relations. Development and Change 27:50I-527.

Lohmann, Roger Ivar

2000 Cultural Reception in the Contact and Conversion History of the Asabano of Papua New Guinea. PhD dissertation, University of Wisconsin.

Macintyre, Martha, and Simon Foale

2004 Politicised Ecology: Local Responses to Mining in Papua New Guinea. Oceania 74:23I-25I.

May, Ron, and Matthew Spriggs, editors

I990 The Bougainville Crisis. Bathurst: Crawford House.

Melk-Koch, Marion

I989 Auf der Suche nach der Menschlichen Gesellschaft: Richard Thurnwald. Berlin: Reimer.

Morren, George

I98I A Small Footnote to the "Big Walk": Environment and Change among the Miyanmin of Papua New Guinea. Oceania 52:39-65.

O'Connor, $\mathrm{M}$.

I994 Kiunga Then and Now. Paradise I05:4I-44.

otML, Ok Tedi Mining Ltd

2000a Rehabilitation and Closure Plan. <http://www.oktedi.com/odf/links/ reports/2/MCP_Rehab_Cl_plan_summary.pdf> [accessed I I Oct 2003]

200ob Social and Sustainable Development Issues in Relation to Mine Closure. Tabubil: Ok Tedi Mining Ltd.

200I Community Mine Continuation Agreements. <http://www.oktedi .com/community/mineContinuation.php> [accessed Nov 2004]

Polier, Nicole

I996 Of Mines and Min: Modernity and its Malcontents in Papua New Guinea. Ethnology 35:I-I6.

PNG Post-Courier (Port Moresby)

2004 Ok Tedi Still Contributing. Online edition, 4 November. <http:// www.postcourier.com.pg/2004 I I 04/businessor.htm> [accessed 4 Nov 2004]

2005 Call to Link Districts with Kiunga. Online edition, I4 June. <http:// www.postcourier.com.pg/200506I4/newso8.htm> [accessed I4 June 2005] 
PNGSDP, PNG Sustainable Development Program Ltd.

2003 Annual Report 2002. <http://www.pngsdp.com/pubs/2002areport .pdf $>$ [accessed 3 Nov 2004]

2004 Annual Report 2003. <http://www.pngsdp.com/pubs/2003areport .pdf $>$ [accessed 3 Nov 2004]

Quinlivan, Paul

I954 Afek of Telefolmin: A Fabulous Story from New Guinea which Led to a Strange Tragedy. Oceania 25:17-22.

Robbins, Joel

1997 "When Do You Think the World Will End?" Globalization, Apocalypticism and the Moral Perils of Fieldwork in "Last New Guinea." Anthropology and Humanism 22:6-30.

2004 The Globalization of Pentecostal and Charismatic Christianity. Annual Review of Anthropology 33:I I 7-I43.

Rumsey, Alan, and James F Weiner, editors

$200 \mathrm{I}$ Mining and Indigenous Lifeworlds in Australia and Papua New Guinea. Adelaide: Crawford House.

Stewart, Pamela J, and Andrew Strathern

2002 Remaking the World: Myth, Mining and Ritual Change among the Duna of Papua New Guinea. Washington DC: Smithsonian Institution Press.

Stürzenhofecker, Gabriele

1994 Visions of a Landscape: Duna Pre-meditations on Ecological Change. Canberra Anthropology I7 (2): 27-47.

Toft, Susan, editor

I997 Compensation for Resource Development in Papua New Guinea. Boroko, PNG: Law Reform Commission of Papua New Guinea.

Visser, Leontine

200 I Remaining Poor on Natural Riches? The Fallacy of Community Development in Irian Jaya/Papua. Asia Pacific Journal of Anthropology 2 (2): 68-88.

Wardlow, Holly

200 I The Mt Kare Python: Huli Myths and Gendered Fantasies of Agency. In Rumsey and Weiner 200I, 3I-67.

Welsch, Robert

I982a The Experience of Illness among the Ningerum of Papua New Guinea. $\mathrm{PhD}$ dissertation, University of Washington.

I982b Traditional Land Tenure and Multinational Development: The Ok Tedi of Papua New Guinea. Paper presented at the annual meetings of the American Anthropological Association, Washington DC.

World Bank

2000 Report on Ok Tedi Mining Ltd. Mine Waste Management Project 
Risk Assessment and Supporting Documents. Available online from the Mineral Policy Institute at: <http://www.mpi.org.au/oktedi/world _bank_full_report.html> [accessed I I June 2003]

Zimmer-Tamakoshi, Laura

1993 Bachelors, Spinsters and Pamuk Meris. In The Business of Marriage, edited by Richard Marksbury, 83-104. Pittsburgh: University of Pittsburgh Press.

\section{Abstract}

Much of the literature on mining in Papua New Guinea is concerned with the politics of landowner compensation. In the case of the Ok Tedi mine, attention has focused largely on claims for downstream ecological damage and the ensuing settlement on behalf of people living along the Lower Ok Tedi. Like all major mines, however, Ok Tedi has produced a series of large-scale ripple effects throughout the surrounding region, both downstream and upstream. In this article I explore two decades of mine-related transformations among Telefolmin, one of several groups of Min people who are a major source of labor for the Ok Tedi mine. I argue that Ok Tedi provides Telefolmin with the ability to realize a particular form of modernity. For Telefolmin, however, this modernity is rendered insecure by their hinterland status and the prospect of mine closure, sharpening fears that the Telefol experience of modernity may be a fleeting one.

KeYwords: mining, Ok Tedi, Papua New Guinea, regional history, Telefolmin, mine closure 